but are Crown property. The list now contains the names of no less than 3,600 monuments of all kinds, from prehistoric camps, stone circles and barrows to the remains of abbeys, castles, bridges, etc. Several of the buildings of historic interest are still in occupation, and Glasgow Cathedral and Dumblane Cathedral are also maintained by the Commissioners. Although, as is pointed out in an introductory note by the secretary to the Commissioners, the list cannot be regarded as complete or as covering systematically the whole of the more important ancient monuments of Great Britain, and although it is recognised that much has still to be done, it serves to indicate the wealth of antiquity that has been preserved, and the gratitude due to those who fifty years ago initiated the move. ment for the official preservation of historic monuments. In this connexion, however, and in view of the constant alarms as to the preservation of structures of historic interest in London, it may be noted that in Middlesex only two, and in London three, ancient monuments are recorded as under protection.

\section{Civil List Pensions}

Among the Civil list pensions just announced as having been granted on March 14 last are the following :-Mrs. Abbott, in recognition of the services rendered by her husband, the late Mr. W. J. Lewis Abbott, to geology and prehistoric archæology, $£ 110$; Mrs. Cantrill, in recognition of the services rendered by her husband, the late Mr. T. C. Cantrill, to prehistoric archæology, $£ 60$; Mrs. Hart, in recognition of the services of her husband, the late Dr. D. B. Hart, to gynæcology, $£ 80$; Mrs. Stapf, in recognition of the services rendered by her husband, the late Dr. Otto Stapf, to botanical science, $£ 90$.

\section{Cattle Diseases and Milk Production}

TowaRDs the end of 1932, a committee of the Economic Advisory Council was appointed by the Prime Minister to formulate measures to reduce disease among milch cows in Great Britain, for reducing bovine tuberculosis and for improving the milk supply, and to report upon any administrative changes that may be desirable. The report of this Committee, presided over by Sir Frederick Gowland Hopkins, has now been issued (Economic Advisory Council. Report of Committee on Cattle Diseases. London : H.M. Stationery Office. 2s. 6d. net). In the first part, the production and distribution of milk and their relation to cattle diseases and public health are considered. The second part is devoted to a discussion of possible lines of administrative development. In part 3 the Committee's various recommendations are set out in detail, and these with the principal conclusions are summarised in part 4. Owing to the ravages of disease, the useful life of a dairy cow, instead of extending over eight or nine lactations, averages only about $4 \frac{1}{2}$ years, the principal diseases causing this wastage being contagious abortion, tuberculosis, mastitis and Johne's disease.

The effects of pasteurisation are surveyed, and the disadvantages are considered to be too small to outweigh the great advantage of protection from infection. Pasteurisation, however, should be permitted only in approved and tested plants, which should be frequently inspected officially by the sanitary authority during working. For the grading of milk, four new designations are suggested to replace those already existing. The principal measures proposed for improving the milk supply are (1) an extension of routine veterinary inspection, (2) an active policy for the eradication of bovine tuber. culosis, and (3) the bestowal upon certain urban authorities of the right to require pasteurisation of all milk sold within their boundaries which is not either certified or grade $\mathbf{A}$, tuberculin tested. Owing to variations in potency of commercial tuberculins, it is recommended that the Ministry of Agriculture and Fisheries should approve a standard for tuberculin, the product to be sold only to qualified veterinary surgeons.

\section{Researches in Pathology}

THE latest number of the Journal of Pathology and Bacteriology (39, No. 1, July, 1934), a handsome volume of some 250 pages with 52 plates, was issued on July 5 as a birthday greeting to Sir Robert Muir, professor of pathology in the University of Glasgow, on his seventieth birthday. Written entirely by his pupils, it is a fitting tribute to the widespread influence of the doyen of British pathology, and no other of our schools of pathology could have done the like for its revered leader. It contains nineteen substantial contributions to knowledge from a dozen different centres, and among the authors are ten professors of pathology or bacteriology. They cover roughly the whole range of subjects with which pathologists concern themselves. This is a far greater testimony to Sir Robert's power as a teacher than if his disciples were pursuing nothing but his own special interests. The Glasgow school and its leader are still as vigorous as ever, and everyone will wish them well.

\section{The Colorado Beetle}

An article by Mr. J. C. F. Fryer in the Gardener's Chronicle of June 23, 1934, issues a note of warming about the possible spread of the Colorado beetle in Great Britain. For long periods our potato crops remained free from attack by this pest, and even when it appeared at Tilbury in 1901, it was quickly eradicated. Since the War, the beetle has established itself in France, and in August 1933 it re-appeared at Tilbury. Drastic measures to prevent its spread were taken immediately, and whilst it seems possible that they were successful, Mr. Fryer appeals to potato growers to maintain a careful watch for the conspicuous beetle. Partially eaten potato foliage suggests its presence, and close examination should be made for the insect. It has wing cases striped longitudinally with black and yellow, and is about half an inch long. That the pest has not yet estab. lished itself in Great Britain is a matter for congratulation, but continued freedom demands close co-operation from growers. Attacks in their early stages can be controlled with comparative ease, but when a colony is well established, it may have sent individuals to found other colonies. 